\title{
New Report of Two Xanthid Crabs (Crustacea: Decapoda: Brachyura) from Korea
}

\author{
Sang-kyu Lee ${ }^{1}$, Tae Seo Park ${ }^{1,2}$ and Won Kim ${ }^{1, *}$ \\ ${ }^{1}$ School of Biological Sciences, Seoul National University, Seoul 151-747, Korea \\ ${ }^{2}$ Invertebrate Research Division, National Institute of Biological Resources, Incheon 404-708, Korea
}

\begin{abstract}
Two species of xanthids, Actaea polyacantha (Heller, 1861) and Actaeodes hirsutissimus (Rüppell, 1830) collected from Jejudo Island, are newly recorded from Korean waters. Korean Xanthidae now consists of 22 species belonging to twenty genera.
\end{abstract}

Keywords: new record, Actaea polyacantha, Actaeodes hirsutissimus, Decapoda, Korea

\section{INTRODUCTION}

The family Xanthidae MacLeay, 1838 is one of the largest groups in the suborder Brachyura. Though its members are found in a variety of habitats from the intertidal to moderately deep water, they are most abundant in shallow water and coastal reef environments (Davie, 2002).

Until now, 20 species of Xanthidae have been recorded from Korean waters: Actaea semblatae Guinot, 1976, Atergatis floridus (Linnaeus, 1767), Atergatis reticulates De Haan, 1833, Atergatopsis germaini A. Milne Edwards, 1865, Banareia subglobosa (Stimpson, 1858), Calvactaea tumida Ward, 1933, Cycloxanthops tuncatus (De Haan, 1837), Forestia depressa (White, 1847), Gaillardiellus orientalis (Odhner, 1925), Leptodius exaratus (H. Milne Edwards, 1834), Lybia caestifera (Alcock, 1898), Macromedaeus distinguendus (De Haan, 1835), Medaeops granulosus (Haswell, 1882), Microcassiope orientalis Takeda and Miyake, 1969, Nanocassiope alcoki (Rathbun, 1902), Neoliomera insularis (Adams and White, 1849), Novactaea pulchella (A. Milne Edwards, 1865), Palapedia integra (De Haan, 1835), Pilodius nigrocrinitus Stimpson, 1858, Platypodia tomentosa (De Man, 1902) (Kim and Kim, 1997; Ko and Takeda, 1999, 2000; Lee and Ko, 2008; Lee, Kim and Kim, 2008). The continuous taxonomic study on the brachyuran species collected from Korean waters revealed that two crabs, Actaea polyacantha (Heller, 1861) and Actaeodes hirsutissimus (Rüppell, 1830), are new to Korean fauna. The genus Actaeodes Dana, 1851 is reported for the first time in Korea. Now Korean Xanthidae consists of 22 species belonging to 20

*To whom correspondence should be addressed

Tel: 82-2-880-6695, Fax: 82-2-872-1993

E-mail: wonkim@plaza.snu.ac.kr genera.

The abbreviations "cl" and "cw" refer to the carapace length from the front to the posterior dorsal margin of the carapace and to the width of the carapace measured at the widest part, respectively. The abbreviated terminology used for carapace regions mostly follows those of Serène (1984). Materials examined in this study are deposited in the Marine Arthropod Depository Bank of Korea (MADBK), Seoul National University.

\section{SYSTEMATIC ACCOUNTS}

Superfamily Xanthoidea MacLeay, 1938

Family Xanthidae MacLeay, 1838

Subfamily Actaeinae Alcock, 1898

Genus Actaea de Haan, 1833

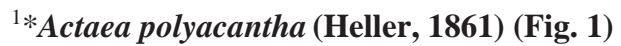

Chlorodius polyacantha Heller, 1861a, p. 11; 1861b, p. 339, pl. 3, fig. 21.

Actaeodes polyacanthus: Miers, 1884, p. 206.

Actaea polyacantha: Rathbun, 1911, p. 222, pl. 18, figs. 5-6; Odhner, 1925, p. 57; Ward, 1933, p. 247; Holthuis, 1953, p. 11; Sakai, 1965, p. 146, pl. 73, fig. 4; McNeill, 1968, p. 72; Guinot, 1971, p. 1071; 1976, p. 236, fig. 40B, pl. 13, fig. 6; Sakai, 1976, p. 443, fig. 234; Serène, 1984, p. 109 (key), p. 112 (key), p. 114, fig. 67, pl. 14E; Dai and Yang, 1991, p. 309, fig. 160A; Muraoka, 1998, p. 41. Actaea spinosissima: Ward, 1942, p. 87.

Materials examined. 1 ovig. 우 (cl $11 \mathrm{~mm}, \mathrm{cw} 16 \mathrm{~mm})$, Beomseom (Jejudo Is.), 26 Aug. 2007, coll. S.K. Lee; 1 우 (cl 8 mm, cw 13 mm), Munseom (Jejudo Is.), 3 Mar. 2009,

$1 *$ 넓은가시옴부채게 (신칭) 

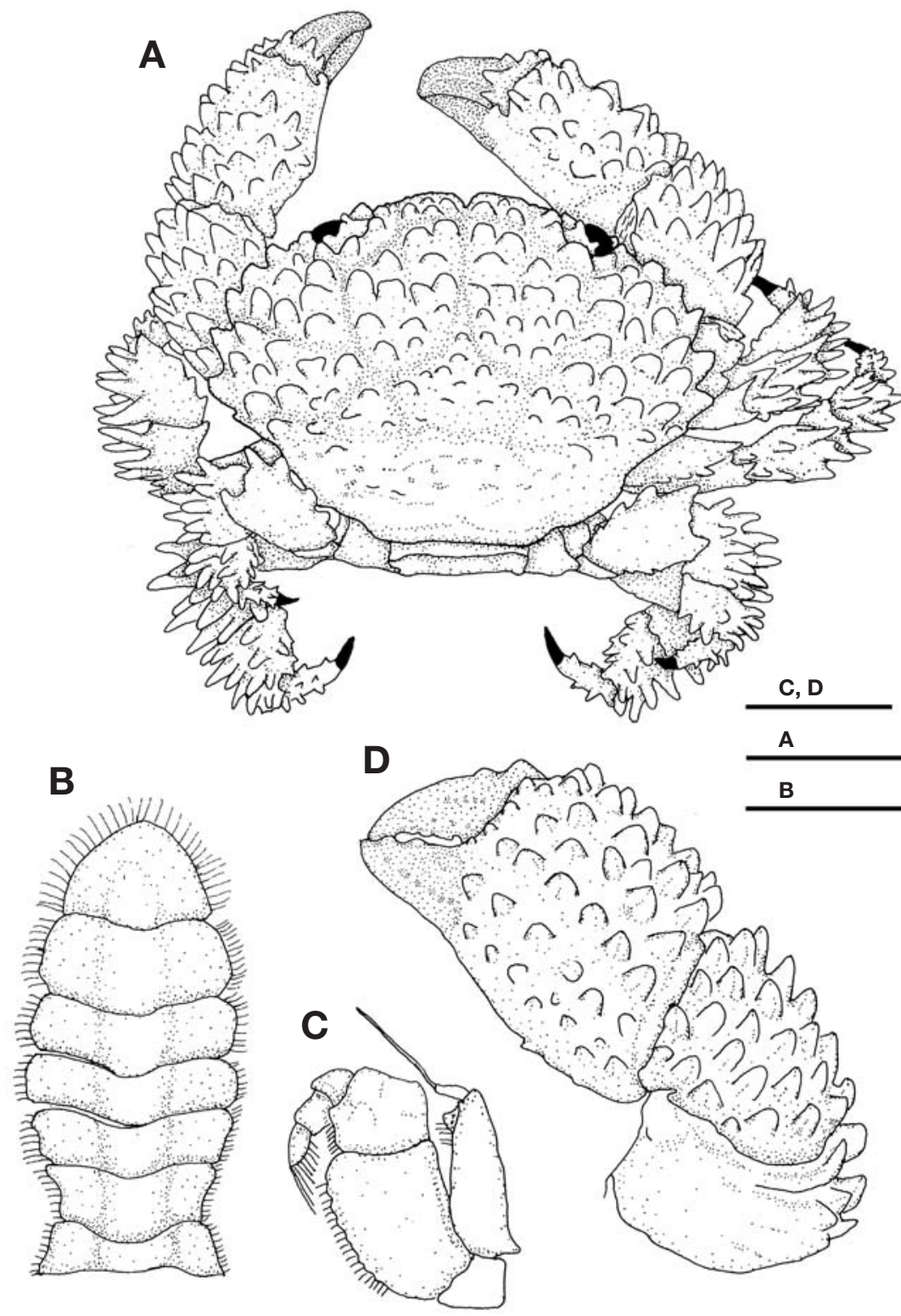

Fig. 1. Actaea polyacantha (Heller, 1861), female. A, whole animal, dorsal view; B, abdomen of female; C, left third maxilliped; $D$, left cheliped, outer view. Scale bars $=2 \mathrm{~mm}(C), 3 \mathrm{~mm}(D), 5 \mathrm{~mm}(A, B)$.

coll. T.S. Park.

Description. Carapace (Fig. 1A) naked, oval; dorsal surface covered with flat-topped black brown tubercles, of which those on $3 \mathrm{M}, 4 \mathrm{M}, 2 \mathrm{R}, 3 \mathrm{R}, 1 \mathrm{P}$, and $2 \mathrm{P}$ somewhat obscure, while those near lateral margins erect and distinct; regions ill-defined except for $2 \mathrm{M}$ and $3 \mathrm{M}$ well demarcated by deep intervening grooves; frontal border rather obscurely bilobated with broad v-shaped median notch; antero-lateral borders with six sharp and slightly curved tubercles including external orbital angle; postero-lateral borders shorter than antero-lateral borders and deeply concave. Supraorbit composed of five tubercles. Eye-stalks short, thick, bearing four to five tubercles. Basal antennal joint entered inner orbital hiatus, but not so deeply. Third maxilliped (Fig. 1C) flatted; ischium longer than broad; merus produced at antero-external angle.

Chelipeds (Fig. 1A, 1D) symmetrical, stout, covered with rather erect and distinct tubercles; outer surface of propodus and carpus bearing tubercles as those on carapace disposed in longitudinal series. Fingers black, stout, without gaping; cutting edges with 3 teeth.

Ambulatory legs (Fig. 1A) bearing long and spine-form 


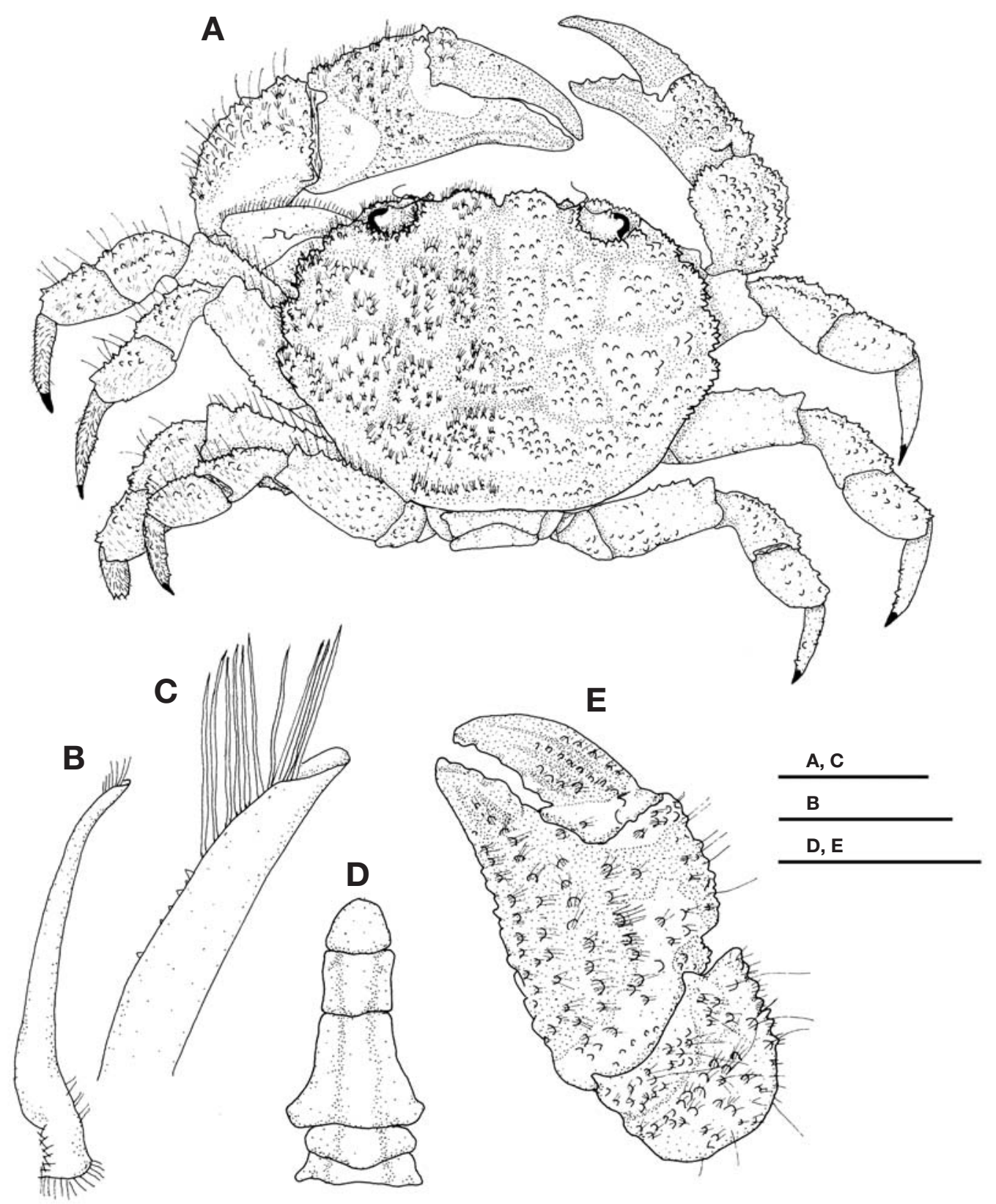

Fig. 2. Actaeodes hirsutissimus (Rüppell, 1830), male. A, whole animal, dorsal view; B, left first pleopod, ventral view; C, tip of left first pleopod; D, abdomen; left cheliped, outer view. Scale bars $=0.5 \mathrm{~mm}(\mathrm{C}), 2 \mathrm{~mm}(B), 5 \mathrm{~mm}(\mathrm{~A}, \mathrm{D}, \mathrm{E})$. Note=Seta on the right part of whole animal are omitted.

tubercles colored black brown distantly along superior borders; merus smooth and glabrous on posterior surface, with 3 to 4 small tubercles on superior borders; dactylus slender, sharp at tip.

Female abdomen (Fig. 1B) composed of seven segments; telson coniform, longer than broad.

Remarks. According to the descriptions by Rathbun (1911), Serène (1984), and Dai and Yang (1991), Actaea polyacantha
(Heller, 1861) has the following characteristics: dorsal surface of carapace covered with flat-topped tubercles; posterior dorsal region without tubercles; median sinus of front narrow; ambulatory legs with long spines on the superior borders (particularly on carpus and propodus). The present specimens agree well with these descriptions but show that the tubercles on $2 \mathrm{R}, 3 \mathrm{R}, 1 \mathrm{P}$, and $2 \mathrm{P}$ are very small or irregular in shape, and the median sinus of the front margin is 
not narrow.

Habitat. Crevices of rocks at low-tide mark.

Distribution. Red Sea, Gulf of Aden, Japan, South China

Sea, Australia, Fiji, Korea (new record).

${ }^{1} *$ Genus Actaeodes Dana, 1851

2*Actaeodes hirsutissimus (Rüppell, 1830) (Fig. 2)

Xantho hirsutissimus Rüppell, 1830, p. 26, pl. 5, fig. 6.

Actaea hirsutissimus: Odhner, 1925, p. 69, pl. 4, fig. 13;

Forest and Guinot, 1961, p.78.

Actaeodes hirsutissimus: Guinot, 1971, p. 1072; Sakai, 1976, p. 488 , pl. 159 , fig. 3 .

Materials examined. $1 \sigma^{\nearrow}(\mathrm{cl} 9 \mathrm{~mm}, \mathrm{cw} 14 \mathrm{~mm})$, Beomseom (Jejudo Is.), 2 Oct. 1995, coll. J. Lee; $1 \sigma^{\nearrow}$ (cl 8 mm, cw 12 mm), 7 June 2001, coll. S.H. Kim.

Description. Carapace (Fig. 2A) 1.5 to 1.6 times broader than long, furnished with short and stiff setae implanted only on beaded granules; surface convex in anterior half and depressed in posterior half; regions separated into lobules by deep and smooth grooves; $2 \mathrm{M}$ entirely divided longitudinally into two parts; each external branch of $2 \mathrm{M}$ with only outline of division on anterior margin; $3 \mathrm{M}$ tripartite; anterior lobe of $3 \mathrm{M}$ long, narrow, hardly developed; frontal border slightly produced and deflected, separated into 2 bluntly round lobes by broad V-shaped notch; antero-lateral borders composed of 4 shallow lobes with tubercles: first to third broadened, last subequal to first; postero-lateral borders very concave, shorter than antero-lateral borders.

Cheliped (Fig. 2E) asymmetrical; merus triquetrous, covered with granules; black pigmentation on fixed finger entirely encircled palm; dactylus black, with triangular teeth on cutting edges; tip of fingers sharp.

Ambulatory legs (Fig. 2A) flat, covered with granules and short hairs on porsterior surface; carpus bearing longitudinal groove in median of superior surface; dactylus short, armed with short claw.

First pleopod (Fig. 2B, 2C) slender and long, with distal portion slightly curved laterally and with tip bluntly spoonshaped.

Male abdomen (Fig. 2D) narrow and long; third to fifth segments fused; sixth segment longer than broad; telson elongated triangle.

Remarks. The areolas on the regions of the carapace of Actaeodes hirsutissimus (Rüppell, 1830) are very similar to those of A. consobrinus (A. Milne Edwards, 1873). The external branch of $2 \mathrm{M}$ of $A$. hirsutissimus has only an outline of division on anterior margin, whereas that of A. consobrinus is whole. The examined specimens have indistinct division of anterior margin on the external branch of $2 \mathrm{M}$. The chelipeds of $A$. hirsutissimus are symmetrical (Serène, 1984; Dai and Yang, 1991) but those of the illustrated specimen in the present study are asymmetrical. However, the characteristics such as the shape of the first pleopod, the black pigmentation on the palm, and the carapace furnished with short and stiff setae implanted only on beaded granules in the present specimens agree well with characteristics of A. hirsutissimus.

Habitat. Shallow waters on coral reefs.

Distribution. China, Japan, Samoa Is., Australia, Philipine, Red Sea, Korea (new record).

\section{ACKNOWLEDGEMENTS}

This work was supported by a grant from Marine Biotechnology Programme funded by Ministry of Land, Transport and Maritime affairs of Korean government and a grant (No. 2006-421) from the Ministry of Environment of the Korean Government. The authors thank to Dr. S.H. Kim and Dr. J. Lee for providing the specimens for this work.

\section{REFERENCES}

Dai, A.Y. and S.-1. Yang, 1991. Crabs of the China seas. China Ocean Press, Beijing, pp. 1-608.

Davie, P.J.F., 2002. Crustacea: Malacostraca: Eucarida (Part 2). Decapoda-Anomura, Brchyura. Zool. Cat. Australia, 19. 3B, pp. 1-641.

Forest, J. and D. Guinot, 1961. Crustacés Décapodes Brachyoures de Tahiti et des Tuamotu. Editions de la Fondation Singer-Polignac, Paris, Préliminaire, pp. 1-195.

Guinot, D., 1971. Recherches préliminaires sur les groupements naturels chez les crustacés decapodes brachyoures. VIII. Synthèse et bibliographie. Bull. Mus. Natn. Hist. Nat., Paris, 42(5): 1063-1090. (in French)

Guinot, D., 1976. Constitution de quelques groupes naturels chez les Crustacés Décapodes Brachyoures: I. La superfamille des Bellioidea et trois sous-familles de Xanthidae (Polydectinae Dana, Trichiinae de Haan, Actaeinae Alcock). Mém. Mus. Natn. Hist. Nat. Nouvelle Série. Série A, Zoologie: 971-308.

Heller, C., 1861a. Synopsis der im Rothen Meer vorkommenden Crustaceen. Verh. Zool. -bot. Ges., Wien, 11: 3-32.

Heller, C., 1861b. Beiträge zur Crustaceen-Fauna des Roten Meeres. Part. 1. Sitz. Akad. Wiss. Wien, Math. -Naturwiss. Klasse, Wien, 43(1): 297-374.

Holthuis, L.B., 1953. Enumeration of the Decapod and Stomatopod Crustacea from Pacific Coral Islands. Atoll Res.

$1 *$ 다모그물등부채게속(신칭), ${ }^{2 *}$ 다모그물등부채게 (신칭) 
Bull., 24: 1-66.

Kim, W. and H.S. Kim, 1997. Lists of animals in Korea (excluding insects). Korean Soc. Syst. Zool., Seoul, pp. 212233.

Ko, H.S. and M. Takeda, 1999. New records of three xanthid crabs (Decapoda: Brachyura: Xanthidae) in Korea. Korean J. Syst. Zool., 15: 75-82.

Ko, H.S. and M. Takeda, 2000. New records of three xanthid crabs (Decapoda, Brachyura) collected from Chejudo Island in Korea. Korean J. Syst. Zool., 16: 31- 37.

Lee, K.H. and H.S. Ko, 2008. First records of three crabs (Crustacea: Decapoda) form Korea. Korean J. Syst. Zool., 24(1): 17-24.

Lee, S.K., S.H. Kim and W. Kim, 2008. Report on four species of crabs (Crustacea: Decapoda: Brachyura) from Korea. Korean J. Syst. Zool., 24(3): 291-297.

McNeill, F.A., 1968. Crustacea, Decapoda and Stomatopoda. Scientific reports Great Barrier Reef Expedition 1928-29, 7(1): 1-98.

Miers, E.J., 1884. Crustacea (Brachyura). In: Report on the zoological collections made in the Indo-Pacific Ocean during the Voyage of H.M.S.Alert 1881-1882. Part I. The collections from Melanesia. Part II. The collections from the Western Indian Ocean. British Mus. (Nat. Hist.), London, 8(1): 178-322.

Milne Edwards, A., 1873. Description de quelques Crustacès nouveaux ou peu connus provenant de Musée de M. C. Godeffroy. J. Mus. Godeffory, 1(4): 77-88.

Muraoka, K., 1998. Catalogue of the Brachyuran and Anomuran Crabs donated by Prof. Dr. Tune Sakai to the Kanaga- wa Prefectural Museum. Cat. Coll. Kanagawa Pref. Mus. Nat. Hist., 11: 5-67.

Odhner, T., 1925. Monographierte Gattungen der Krabbenfamilie Xanthidae. I. Göteb. Vet. Sämh. Handl., 29(1): 3-92.

Rathbun, M.J., 1911. Marine Brachyura. In The Percy Sladen Trust Expedition to the Indian Ocean in 1905, under the Leadership of Mr J. Stanley Gardiner. Vol. III, part II, No. XI. Trans. Linn. Soc. London, (Zool.), (2) 14(2): 191-261.

Rüppell, E.S., 1830. Beschreibungen und Abbildungen von 24 Arten kurzschwänzigen krabben, als Beiträge zur Naturgeschichte des Rothen Meeres. H. L. Brönner, Frankfurt a. M.: 1-28.

Sakai, T., 1965. The Crabs of Sagami Bay, Maruzen Co. Ltd., Tokyo, pp. 1-206 (English), pp. 1-92 (Japanese).

Sakai, T., 1976. Crabs of Japan and the Adjacent Seas. Kodansha Ltd, Tokyo, pp. 1-773.

Serène, R., 1984. Crustacés Décapodes Brachyoures de l'Océan Indien occidental et de la Mer Rouge, Xanthoidea: Xanthidae et Trapeziidae. Avec un addendum par Crosnier (A): Carpiliidae et Menippidae. Faune Tropicale, no. XXIV: 1349. (In French) (Translated into English by R.W. Ingle).

Ward, M., 1933. The true crabs of the Capricorn Group, Queensland (Class Crustacea, Order Decapoda Brachyura). Part 1. Xanthidae. Aust. Zool., Sydney, 7(5): 237-255.

Ward, M., 1942. Notes on the Crustacea of the Desjardins Museum, Mauritius Institute, with descriptions of new genera and species. Bull. Mauritius Inst., Port Louis, 2(2): 49-113.

Received February 19, 2010 Accepted March 11, 2010 